\title{
Pengaruh Jenis dan Kosentrasi Daging Ikan terhadap Mutu Organoleptik Bubur Ikan
}

\author{
Muhammad Akbar ${ }^{1}$, Umar Tangke $^{2 \bowtie}$ dan Vanessa N. L. Lekahena ${ }^{2}$ \\ ${ }^{1}$ Prodi THP FAPERTA Universitas Muhammadiyah Maluku Utara, Ternate, Indonesia \\ ${ }^{2}$ Staf Pengajar Prodi THP FAPERTA Universitas Muhammadiyah Maluku Utara. Ternate. Indonesia, \\ Email : umbakahaka@gmail.com; enchalekahena@gmail.com

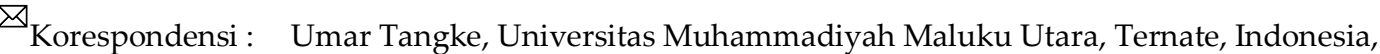 \\ Email : umbakahaka@gmail.com
}

\begin{abstract}
ABSTRAK.
Bubur ikan adalah salah satu jenis diversifikasi dan merupakan produk olahan lokal yang selama ini sudah dikenal luas oleh masyarakat Maluku sebagai olahan pada acara adat, keagamaan sampai pada penyajiannya sebagai makanan konsumsi pada bulan ramadhan. Pembuatan bubur ikan oleh masyarakat Maluku umumnya masih bersifat turun temurun dimana mereka lebih mengandalkan pengalaman, hal ini tentunya akan sangat berdampak pada penggunaan bahan dan cita rasa produk yang dihasilkan. Penelitian ini dilaksanakan untuk mencari formulasi yang tepat untuk jenis bubur ikan terkait dengan penggunaan jenis dan konsentrasi daging ikan. Dengan menggunakan rancangan acak lengkap faktorial sebagai alat analisis dengan tujuan untuk mengetahui mutu organoleptik bubur ikan dengan menggunakan jenis dan konsentrasi yang berbeda serta mendapatkan formula yang terbaik. Hasil penelitian menunjukan bahwa sebagian besar perlakuan tidak berpengaruh nyata terhadap mutu organoleptik bubur ikan dimana pada perlakuan jenis ikan nilai mutu organoleptik tekstur berpengaruh nyata sedangkan kenampakan, bau bubur ikan tidak berpengaruh nyata, aroma, rasa dan warna, pada perlakuan konsentrasi daging ikan semua mutu organoleptik tidak berpengaruh nyata, sedangkan untuk perlakuan interaksi hanya mutu organoleptik kenampakan yang berpengaruh nyata dan pada perlakuan interaksi antara jenis ikan dan konsentrasi daging ikan perlakuan terbaik adalah pada perlakuan $A_{1} B_{1}, A_{1} B_{2}, A 2 B_{1}$, $A_{2} B_{2}$, dan $A_{2} B_{3}$. Dimana perlakuan $A_{1}$ adalah jenis ikan layang, $A_{2}$ jenis ikan julung, $B_{1}$ konsentrasi $25 \mathrm{~g}$, $\mathrm{B}_{2}$ konsentrasi $50 \mathrm{~g}$ dan $\mathrm{B}_{3}$ konsentrasi $75 \mathrm{~g}$.
\end{abstract}

\section{Keyword: Bubur ikan, Kosentrasi, Ikan layang, Ikan julung}

\section{PENDAHULUAN}

Pemanfaatan sumber daya ikan di Indonesia belum secara optimal dilakukan terutama untuk diversifikasi produk olahan perikanan. Diversifikasi produk olahan ikan merupakan penganekaragaman produk hasil perikanan yang berbahan baku ikan, yang belum atau sudah dimanfaatkan dengan memperhatikan faktor mutu dan gizi, guna peningkatan konsumsi ikan baik secara kualitas maupun kuantitas serta peningkatan nilai jual (Trilaksani dan bambang, 2008).

Ikan merupakan sumber protein, lemak, vitamin, dan mineral yang sangat baik. Keunggulan utama protein ikan dibandingkan produk lainnya terletak pada kelengkapaan komposisi asam amino dan kemudahan dicerna, dan mengandung asam lemak, terutama asam lemak omega-3 yang sangat penting bagi kesehatan. Dibandingkan dengan lemak hewani lainnya, lemak ikan sangat sedikit mengandung kolesterol, sehingga menguntungkan bagi keseehatan, karena kolesterol yang berlebih dapat menyebabkan terjadinya penyumbatan pembuluh darah dan penyakit jantung. Selain protein tinggi ikan juga mengandung sejumlah vitamin dan mineral yang berimbang, vitamin yang banyak pada ikan adalah vitamin yang mudah larut dalam lemak (Vitamin A dan D). Sedangkan mineral yang 
dominan adalah kalsium, fosfor, iodium, besi, dan selenium. Zat-zat gizi tersebut bermanfaat untuk mencegah berbagai penyakit (Astawan, 2004).

Diversifikasi produk perikanan bertujuan untuk meningkatkan nilai tambah produksi perikanan yang baik berasal dari penangkapan, sehinggah dapat memperkenalkan produk-produk perikanan ke pasar dan diterima oleh kosumen secara luas (Suprapti dan Rorong, 2003). Pengembangan produk perikanan merupakan suatu proses untuk menciptakan produk-produk baru yang biasanya dikaitkan dengan kebutuhan konsumen atau pasar dapat berupa produk inuvatif, modifikatif dan imitatif, yang dapat menarik minat konsumen dan pasar. Bentuk diversifikasi olahan ikan dapat berupa bakso, otak-otak dan bubur ikan.

Bubur ikan adalah produk olahan lokal yang selama ini sudah dikenal luas oleh masyarakat Maluku sebagai olahan pada acara adat, keagamaan sampai pada penyajiannya sebagai makanan konsumsi pada bulan ramadhan. Pembuatan bubur oleh masyarakat Maluku umumnya masih bersifat turun temurun dimana mereka lebih mengandalkan pengalaman pada pembuatan bubur ikan tersebut. Hal ini tentunya akan sangat berdampak pada penggunaan bahan dan cita rasa produk yang dihasilkan. Penelitian ini bertujuan untuk mengetahui mutu organoleptik ikan dengan menggunakan jenis dan konsentrasi yang berbeda serta mendapatkan formula yang terbaik dalam mengolah bubur ikan. Sedangkan manfaat dari penelitian ini adalah sebagai bahan teori dan informasi untuk penelitian selanjutnya.

\section{METODOLOGI PENILITIAN}

Penelitian ini dilaksanakan pada bulan November sampai dengan Desember 2017 di Laboratorium Pengolahan Hasil Perikanan Universitas Muhammadiyah Maluku Utara, untuk proses pembuatan dan uji sensori hedonik. Bahan yang digunakan dalam penelitian ini adalah beras, bawang merah, bawang putih, daun salam, cabe besar, lada halus, santan kelapa, kecap, jintan, ketumbar, mentega, cengkeh, pala, gula,garam, ikan garam, kayu manis dan minyak kelapa. Sedangkan peralatan yang digunakan dalam penelitian ini adalah gelas ukur, timbangan elektrik, blender, kompor, wajan, tempat ulek, panci, pisau, penggorengan, baskom stenlis, lembaran uji sensori hedonik (score sheet) dan pulpen. Tahapan yang akan dilaksanakan dalam kegiatan penelitian ini dapat dilihat pada diagram (Gambar 1).

Penelitian ini menggunakan Ragam Faktorial Experimen Rancangan Acak Lengkap (RAL) dengan perlakuan $A$ jenis ikan $\left(A_{1}=\right.$ ikan layang, $A_{2}=i k a n$ Julung), perlakuan $B$ konsnetrasi daging $\left(B_{1}\right.$ $=12.5 \% / 25$ gr, $B_{2}=25 \% / 50$ gr dan $B_{3}=37.5 \% / 75$ gr . Data hasil uji skoring dianalisis dengan analisis ragam Faktorial Experimen Rancangan Acak Lengkap (RAL) yang model matematikanya (Steel dan Torrie, 1993). adalah :

$$
\mathrm{Y}_{i j k}=\mu+\alpha_{i}+\beta_{j}+(\alpha \beta)_{i j}+\mathrm{E}_{\mathrm{ijk}}(i=1,2,3, j=1,2, k=1,2,3,4)
$$

Ket :

$$
\begin{array}{ll}
\mathrm{Y}_{i j k} & =\text { Nilai pengamatan pada faktor } \mathrm{A} \text {, taraf }-\mathrm{i} \text {, faktor } \mathrm{B} \text { taraf }-\mathrm{j} \text {, dan ulangan ke }-k \\
\mu & =\text { Nilai tengah umum } \\
\alpha_{i} & =\text { Pengaruh taraf }-\mathrm{i} \text { dari faktor } \mathrm{A} \\
\beta_{j} & =\text { Pengaruh taraf }-\mathrm{j} \text { cari faktor } \mathrm{B} \\
(\alpha \beta)_{i j}= & \text { Pengaruh interaksi taraf ke- } \mathrm{i} \text { dari faktor A dan taraf ke- } \mathrm{j} \text { dari faktor } \mathrm{B} \\
\mathrm{E}_{\mathrm{ijk}}= & \text { Pengaruh sisa galat (galat percobaa) taraf ke- } \mathrm{i} \text { dari faktor A dan taraf ke- } \mathrm{j} \text { dari } \\
& \text { faktor } \mathrm{B} \text { pada ulangan yang ke- } \mathrm{k}
\end{array}
$$




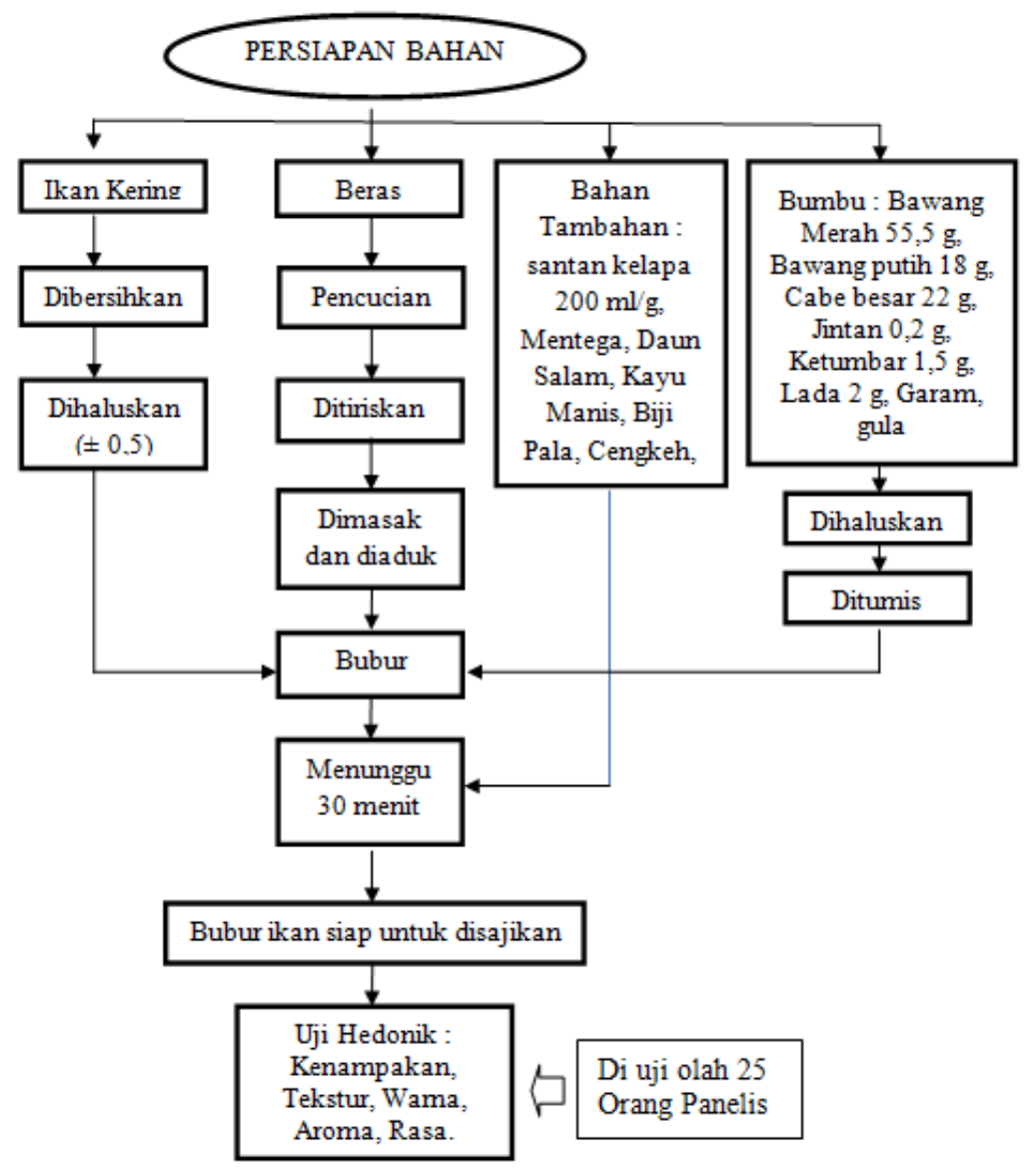

Gambar 1. Diagram Alir Bubur Ikan

\section{HASIL DAN PEMBAHASAN}

\subsection{Karakteristik Nilai Mutu Organoleptik}

Pengetahuan tentang baik dan buruknya suatu produk pangan adalah suatu hal mendasar untuk dapat mengetahui apakah produk tersebut dapat layak untuk di konsumsi atau di pasarkan. Cara yang umumnya dilakukan adalah dengan melihat karakteristik baik dan buruknya produk pangan tersebut, untuk itu maka dilakukan uji oragnoleptik yang tujuan untuk menilai suatu produk makanan atau pangan sebelum dipasarkan. Pengujian organoleptik terhadap sesuatu makanan adalah penilaian menggunakan alat indera uji penglihatan, pengecap dan pembau dimana dengan uji ini dapat diketahui mutu atau penerimaan suatu produk (Soekarto dan Hubeis, 2000). Karakteristik organoleptik bubur ikan dengan menggunakan uji organoleptik, dimana mutu ikan yang di uji secara organolpetik adalah kenampakan, aroma, tekstur, rasa dan warna bubur ikan.

Probabilitas pengujian organoleptik pada perlakuan jenis ikan dan konsentrasi daging serta perlakuan interaksi adalah jika nilai $F_{\text {hit }}$ lebih besar dari $F_{\text {tabel }}$ dan nilai signifikansi lebih kecil atau sama dengan 0.05 , maka $\mathrm{H}_{0}$ diterima, jika $\mathrm{F}_{\text {hit }}$ lebih kecil dari $\mathrm{F}_{\text {tabel }}$ dan nilai signifikansi lebih besar dari 0.05 , maka $\mathrm{H}_{1}$ diterima.

\subsection{Kenampakan}

Kenampakan merupakan parameter yang dapat dilihat secara visual yang menyebabkan panelis tertarik dan suka pada produk tersebut, kenampakan suatu produk makanan merupakan faktor penarik utama sebelum panelis menyukai sifat mutu sensori yang lainnya seperti rasa, bau dan tekstur. Pada umumnya konsumen memilih makanan yang memiliki kenampakan menarik (Soekarto dan Hubeis, 2000).

Hasil analisis ragam (uji F) untuk melihat pengaruh yang diberikan dari dua perlakuan (jenis ikan dan konsentrasi daging ikan) serta perlakuan interaksi terhadap penampakan dendeng ikan madidihang dapat dilihat pada Tabel 1 . Hasil uji $\mathrm{F}$ pada Tabel 1 dapat dilihat bahwa pada perlakuan jenis dan konsentrasi daging ikan nilai $F_{\text {hit }}$ masing-masing adalah 0.900 dan 0,100 dan nilai signifikansi adalah 0.362 dan 0.906 lebih besar dari $\alpha(0.05)$, sehingga dapat disimpulkan bahwa 
untuk perlakuan jenis ikan dan konsentrasi daging ikan tidak berpengaruh nyata terhadap mutu organoleptik kenampakan bubur ikan. Pada perlakuan interaksi nilai $F_{\text {hit }}(3.900)$ terlihat lebih besar dari nilai $F_{\text {tabel }}$ (3.354) dengan nilai signifikansi adalah 0.050, sehingga dapat disimpulkan bahwa perlakuan interaksi berpengaruh nyata terhadap mutu organoleptik kenampakan bubur ikan. Hasil uji lanjut interaksi didapat bahwa hanya perlakuan konsentrasi $\mathrm{B}_{1}$ dan $\mathrm{B}_{2}$ yang berbeda nyata.

Tabel 1. Hasil Analisis Ragam Kenampakan Bubur Ikan

\begin{tabular}{lrrrrrr}
\hline \multicolumn{1}{c}{ Source } & $\begin{array}{c}\text { Type III Sum } \\
\text { of Squares }\end{array}$ & df & Mean Square & $\mathbf{F}_{\text {Hit }}$ & $\begin{array}{c}\text { F Fabel } \\
(\boldsymbol{\alpha = 0 . 0 0 5 )})\end{array}$ & Sig. \\
\hline Intercept & 401.389 & 1 & 401.389 & 722.500 & & .000 \\
Jenis Ikan & .500 & 1 & .500 & .900 & 4.413 & .361 \\
Konsentrasi & .111 & 2 & .056 & .100 & 3.354 & .906 \\
Ikan * Konsentrasi & 4.333 & 2 & 2.167 & 3.900 & 3.354 & .050 \\
Total & 413.000 & 18 & & & & \\
\hline
\end{tabular}

a. $R$ Squared = .426 (Adjusted $R$ Squared $=.187$ )

Perlakuan interaksi ini dilakukan untuk melihat hasil terbaik dari uji organoleptik pada perlakuan interaksi A dan B untuk kenampakan bubur ikan. Hasil uji untuk perlakuan interaksi, dapat dilihat bahwa kenampakan bubur ikan terbaik terdapat pada perlakuan $A_{1} B_{2}$ dan $A_{2} B_{3}$.

\subsection{Aroma}

Kelezatan suatu makanan sangat ditentukan oleh faktor aroma, dalam banyak hal aroma menjadi daya tarik tersendiri dalam menentukan rasa enak dari suatu produk makanan itu sendiri (Soekarto dan Hubeis, 2000). Aroma lebih banyak berhubungan dengan indera penciuman (hidung). Pada umumnya bau yang diterima oleh hidung dan otak lebih banyak merupakan campuran 3 bau yaitu asam, tengik dan hangus (Winarno, 1979).

Tabel 2. Hasil Analisis Ragam Aroma Bubur Ikan

\begin{tabular}{|c|c|c|c|c|c|c|}
\hline Source & $\begin{array}{l}\text { Type III Sum } \\
\text { of Squares }\end{array}$ & df & Mean Square & $\mathbf{F}_{\text {hit }}$ & $\begin{array}{c}\mathbf{F}_{\text {Tabel }} \\
(\alpha=0.005)\end{array}$ & Sig. \\
\hline Intercept & 490.889 & 1 & 490.889 & 736.333 & & .000 \\
\hline Jenis Ikan & .222 & 1 & .222 & .333 & 4.413 & .574 \\
\hline Konsentrasi & .778 & 2 & .389 & .583 & 3.354 & .573 \\
\hline Ikan * Konsentrasi & .111 & 2 & .056 & .083 & 3.354 & .921 \\
\hline Total & 500.000 & 18 & & & & \\
\hline
\end{tabular}

a. $R$ Squared = .122 (Adjusted $R$ Squared = -.244)

Hasil analisis ragam (uji F) dengan menggunakan softwere SPSS untuk melihat pengaruh yang diberikan dari dua perlakuan (jenis dan konsentrasi daging ikan) terhadap aroma bubur ikan pada Tabel 2 dapat dilihat nilai hasil analisis ragam menunjukan bahwa aroma untuk perlakuan jenis, konsentrasi dan perlakuan interaksi tidak memberikan pengaruh yang nyata, ini dapat dilihat dengan nilai $\mathrm{F}_{\text {hit }}$ masing-masing adalah $0.333,0.583$ dan 0.083 serta nilai signifikansi masing-masing perlakuan adalah $0.574,0.573$ dan 0.921 yang lebih besar dari nilai $\alpha(0.05)$. Grafik pada perlakuan interaksi (Gambar 3), dapat dilihat bahwa nilai penerimaan aroma terbaik adalah pada perlakuan $\mathrm{A}_{1} \mathrm{~B}_{3}$.

\subsection{Tekstur}

Tekstur merupakan komponen dan unsur struktur yang ditata dan digabung menjadi mikro dan makro struktur dalam segi aliran deformasi.Tekstur suatu bahan tergantung pada keadaan fisik bahan tersebut sehingga penilaian terhadap tekstur dapat berupa kekerasan, kerenyahan dan elastisitas (De Man, 1997 dalam Thalib, 2009).

Tabel 3 menunjukan hasil analisis ragam (uji F) dengan menggunakan softwere SPSS untuk melihat pengaruh yang diberikan dari dua perlakuan (jenis dan konsentrasi daging ikan) terhadap tekstur bubur ikan, dimana hasil analisis ragam tersebut dapat dijelaskan bahwa tekstur untuk perlakuan jenis ikan (perlakuan A) memberikan pengaruh yang nyata, ini dapat dilihat dengan nilai $\mathrm{F}_{\text {hit }}$ 
(6.125), lebih besar dari $F_{\text {tabel }}$ dan nilai signifikansi (0.029) yang lebih kecil dari 0.05, sedangkan hasil analisis perlakuan konsentrasi dagin ikan (perlakuan B) dan interaksi tidak memberikan pengaruh yang nyata dengan nilai signifikansi lebih besar dari 0.05. Hasil Uji Lanjut tekstur pada perlakuan jenis ikan didapat bahwa perlakuan jenis ikan $A_{1}$ berbeda nyata dengan $A_{2}$.

Tabel 3. Hasil Analisis Rata-Rata Tekstur Bubur Ikan

\begin{tabular}{lrrrrrr}
\hline \multicolumn{1}{c}{ Source } & $\begin{array}{c}\text { Type III Sum } \\
\text { of Squares }\end{array}$ & df & Mean Square & F & $\begin{array}{c}\text { F }_{\text {Tabel }} \\
(\boldsymbol{\alpha = 0 . 0 0 5 )}\end{array}$ & Sig. \\
\hline Intercept & 440.056 & 1 & 440.056 & 990.125 & & .000 \\
Jenis Ikan & 2.722 & 1 & 2.722 & 6.125 & 4.413 & .029 \\
Konsentrasi & .444 & 2 & .222 & .500 & 3.354 & .619 \\
Ikan * Konsentrasi & .444 & 2 & .222 & .500 & 3.354 & .619 \\
Total & 449.000 & 18 & & & & \\
\hline
\end{tabular}

a. $R$ Squared = .404 (Adjusted $R$ Squared = .155)

Nilai analisis interaksi tekstur bubur ikan, dimana dapat dilihat bahwa nilai penerimaan bubur ikan tertinggi oleh panelis terdapat pada perlakuan $A_{2} B_{1}, A_{2} B_{2}$ dan $A_{2} B_{3}$. Perlakuan $A_{2} B_{1}, A_{2} B_{2}$ dan $A_{2} B_{3}$, masing-masing menggunakan jenis ikan julung kering dengan konsentrasi daging ikan $25 \%$, $50 \%$ dan $75 \%$.

\subsection{R a s a}

Cita rasa merupakan faktor penentu daya terima konsumen terhadap produk pangan yang dihasilkan (Naruki, 1991). Rasa lebih banyak dinilai menggunakan indra pengecap atau lidah. Faktor rasa memegang peran penting dalam pemilihan produk oleh konsumen, karena walaupun kandungan gizinya baik tetapi rasanya tidak dapat diterima oleh kosumen maka target meningkatkan gizi masyarakat tidak dapat tercapai dan produk tersebut tidak laku (Winarno, 1997).

Tabel 4. Hasil Analisis Rata-Rata Rasa Bubur Ikan

\begin{tabular}{lrrrrrr}
\hline \multicolumn{1}{c}{ Source } & $\begin{array}{c}\text { Type III Sum } \\
\text { of Squares }\end{array}$ & df & Mean Square & F & $\begin{array}{c}\text { F }_{\text {Tabel }} \\
(\boldsymbol{\alpha = 0 . 0 0 5 )}\end{array}$ & Sig. \\
\hline Intercept & 490.889 & 1 & 490.889 & 736.333 & & .000 \\
Jenis Ikan & .222 & 1 & .222 & .333 & 4.413 & .574 \\
Konsentrasi & .778 & 2 & .389 & .583 & 3.354 & .573 \\
Ikan * Konsentrasi & .111 & 2 & .056 & .083 & 3.354 & .921 \\
Total & 500.000 & 18 & & & & \\
\hline
\end{tabular}

a. $R$ Squared = .122 (Adjusted $R$ Squared = -.244)

Hasil analisis ragam untuk rasa dari perlakuan jenis dan konsentrasi daging ikan (Tabel 4) dapat dijelaskan bahwa rasa untuk perlakuan jenis ikan, konsentrasi daging ikan dan perlakuan interaksi tidak berpengaruh nyata terhadap rasa bubur ikan. Hal ini terlihat dari nilai uji rata-rata dari dua perlakuan dan tiga ulangan memiliki nilai rata-rata yang hampir sama dan juga secara jelas dapat terlihat pada $\mathrm{F}_{\text {hit }}$ dimana nilai $\mathrm{F}_{\text {hit }}$ dari masing-masing perlakuan adalah $0.333,0.583$ dan 0.083 yang lebih kecil dari $\mathrm{F}_{\text {tabel }}$ serta nilai signifikansi yang lebih besar dari $\alpha(0.05)$. Nilai analisis interaksi rasa bubur ikan tertinggi oleh panelis terdapat pada perlakuan $A_{1} B_{3}$, dimana pada perlakuan $A_{1} B_{3}$ menggunakan jenis ikan laying dengan konsentrasi $75 \%$.

\subsection{Warna}

Warna produk pangan merupakan daya tarik utama sebelum konsumen menal atau menyukai sifat-sifat lainnya, dengan melihat warna, konsumen telah dapat menilai mutu bahan pangan dengan cepat dan mudah (Soekarto, 1985). Tabel 5 menunjukan hasil analisis ragam untuk mutu warna bubur ikan pada perlakuan jenis dan konsentrasi daging ikan serta perlakuan interaksi antara jenis dan konsentrasi daging ikan dapat dilihat pada Tabel 5.

Pada Tabel 5, dapat dijelaskan bahwa pada perlakuan jenis ikan, konsentrasi serta interaksi jenis dan konsentrasi daging ikan tidak berpengaruh nyata terhadap nilai mutu warna bubur ikan. Hal ini terlihat dengan nilai $F_{\text {hit }}$ masing-masing perlakuan dengan nilai $0.400,0.900$ dan 0.100 lebih 
kecil dari Ftabel serta nilai signifikansi yang lebih besar dari $\alpha(0.05)$. Nilai analisis interaksi dimana penerimaan bubur ikan tertinggi oleh panelis terdapat pada perlakuan $A_{2} B_{1}$ dan $A_{2} B_{3}$, dimana pada perlakuan $A_{1} B_{3}$ menggunakan ikan julung dengan konsentrasi 25 dan 75\%.

Tabel 5. Hasil Analisis Rata-Rata Warna Bubur Ikan

\begin{tabular}{lrrrrrr}
\hline \multicolumn{1}{c}{ Source } & $\begin{array}{c}\text { Type III Sum } \\
\text { of Squares }\end{array}$ & df & Mean Square & F & $\begin{array}{c}\text { F Tabel }_{(\boldsymbol{\alpha = 0 . 0 0 5 )}} \\
\text { Sig. }\end{array}$ \\
\hline Intercept & 450.000 & 1 & 450.000 & 810.000 & .000 \\
Jenis Ikan & .222 & 1 & .222 & .400 & 4.413 & .539 \\
Konsentrasi & 1.000 & 2 & .500 & .900 & 3.354 & .432 \\
Ikan * Konsentrasi & .111 & 2 & .056 & .100 & 3.354 & .906 \\
Total & 458.000 & 18 & & & & \\
\hline
\end{tabular}

a. $R$ Squared $=.167$ (Adjusted $R$ Squared $=-.181$ )

\subsection{Konsistensi}

Konsistensi adalah analisis gabungan nilai rata-rata dari semua perlakuan. Analisis konsistensi dilakukan dengan tujuan untuk melihat produk terbaik yang diterima melalui gabungan semua kriteria mutu organoleptik. Hasil analisis ragam untuk nilai konsisten yang merupakan rekapan dari semua nilai atau nilai rerata dari semua hasil uji didapat bahwa nilai konsistensi bubur ikan pada perlakuan jenis dan konsentrasi daging ikan serta perlakuan interaksi antara jenis dan konsentrasi daging ikan dapat dilihat pada Tabel 5 .

Tabel 5. Hasil Analisis Rerata Nilai Konsistensi Bubur Ikan

\begin{tabular}{lrrrrrr}
\hline \multicolumn{1}{c}{ Source } & $\begin{array}{c}\text { Type III Sum } \\
\text { of Squares }\end{array}$ & Df & Mean Square & F & $\begin{array}{c}\text { FTabel } \\
(\boldsymbol{\alpha = 0 . 0 0 5 )}\end{array}$ & Sig. \\
\hline Intercept & 440.056 & 1 & 440.056 & 7921.000 & & .000 \\
Ikan & .056 & 1 & .056 & 1.000 & 4.413 & .337 \\
Konsentrasi & .111 & 2 & .056 & 1.000 & 3.354 & .397 \\
Ikan * Konsentrasi & .111 & 2 & .056 & 1.000 & 3.354 & .397 \\
Total & 441.000 & 18 & & & & \\
\hline
\end{tabular}

a. R Squared $=.167$ (Adjusted $R$ Squared $=-.181$ )

Pada Tabel 5, dapat dijelaskan bahwa pada perlakuan jenis ikan, konsentrasi serta interaksi jenis dan konsentrasi daging ikan tidak berpengaruh nyata terhadap nilai konsistensi bubur ikan.Hal ini terlihat dengan nilai $F_{\text {hit }}$ masing-masing perlakuan dengan nilai 1.000, 1.000 dan 1.100 lebih kecil dari $\mathrm{F}_{\text {tabel }}$ yang masing-masing 4.413 untuk perlakuan jenis ikan, 3.354 untuk perlakuan konsentrasi serta 3.354 untuk perlakuan interaksi. Selain itu dapat dilijat pada nilai signifikansi yang lebih besar dari $\alpha(0.05)$. Nilai analisis interaksi dimana penerimaan bubur ikan tertinggi oleh panelis terdapat pada perlakuan $A_{1} B_{1}, A_{1} B_{2}, A_{2} B_{1}, A_{2} B_{2}$, dan $A_{2} B$.

\section{PENUTUP}

Pada perlakuan jenis ikan nilai mutu organoleptik tekstur berpengaruh nyata sedangkan mutu organoleptik kenampakan, bau bubur ikan tidak berpengaruh nyata, aroma, rasa dan warna. Pada perlakuan konsentrasi daging ikan semua nilai mutu organoleptik tidak berpengaruh nyata, sedangkan untuk perlakuan interaksi hanya nilai mutu organoleptik kenampakan yang berpengaruh nyata. Pada perlakuan interaksi antara jenis ikan dan konsentrasi daging ikan perlakuan terbaik adalah pada perlakuan $A_{1} B_{1}, A_{1} B_{2}, A_{2} B_{1}, A_{2} B_{2}$, dan $A_{2} B_{3}$. Dimana perlakuan $A_{1}$ adalah jenis ikan layang, $A_{2}$ jenis ikan julung, $B_{1}$ konsentrasi 25 gr, $B_{2}$ konsentrasi 50 gr dan $B_{3}$ konsentrasi 75 gr.

Pada penelitian ini hampir semua perlakuan tidak memberikan pengaruh nyata terhadap nilai mutu organoleptik daging ikan sehingga perlu adanya penelitian lanjutan dengan menggunakan konsentrasi daging ikan yang agak besar dari penelitian ini. 


\section{DAFTAR PUSTAKA}

Anggraeni, 2007. Analisis Statistik Tentang Tingkat Keekonomisan dan Kadar Gizi dari Beberapa Merek Bubur Susu Instan (Studi Kasus Pertambahan Berat Badan Bayi Berdasarkan Bubur Instan Ekonomis. Sikripsi. Fakultas Matematika Dan Ilmu Pengetahuan Alam Institut Teknologi Sepuluh Nopember.

Astawan, M. 2004. Tetap Sehat dengan Produk Makanan Olahan. Tiga Serangkai. Solo.

Gunarso, W. 1985. Tingkah Laku Ikan dalam Hubungannya dengan Alat Tangkap, Metode dan Taktik Penangkapan. Institut Pertanian Bogor, Bogor. Hal : 149.

Larasati, Kajian Formulasi Bubur Bayi Instan berbahan Dasar Pati Garut Maranta Arundinaceae L Sebagai Makanan pendamping ASI (MP - ASI) terhadap sifat Fisik dan Organoleptik. Jurnal Teknologi Pangan Dan Hasil Pertanian Uni-versitas Semarang.

Muchtadi D, Rustady T. 1989. Teknologi pengolahan Pangan. Departemen Pendidikan Dan Kebudayaan. Direktorat Jendral Pendidikan Tinggi Universitas Pangan Dan Gizi. IPB. Bogor.

Nontji, A. 2002. Laut Nusantara. Cetakan ketiga. Penerbit Djambatan, Jakarta: 367 hal.

Peristiwady, D. 2006. Ikan - ikan Laut Ekonomis Penting di Indonesia; Petunjuk Identifikasi. Lipi Press. Jakarta.

Reppie, E., E. P. Sitanggang, dan J. Budiman, 2011. Pendugaan potensi dan musim penangkapan ikan julung-julung (Hemiramphus sp.) berdasarkan hasil tangkapan soma giop di perairan Selat Bangka, Kabupaten Minahasa Utara, Sulawesi Utara. Pacific Journal Regional Board of Research North Sulawesi. Vol 1 No. 6, Januari 2011.

ISSN 1907-9672. (1010-1014). Saanin, H. 1968. Takonomi dan kunci Identifikasi Ikan. Jilid I dan II. Bina Cipta. Bogor.

Soekarto, S.T., 1985 Penelitian Organoleptik untuk Industri Pangan dan Hasil Pertanian. Bhrathara Karya Aksara, Jakarta.

Sunarjo .1990 . Analisa Parameter Pertumbuhan Ikan Layang Deles (Decapterus macrosoma Blkr) di Perairan Laut Jawa Bagian Timur. (Skripsi) Fakultas Peternakan Universitas Diponegoro Semarang.

Supraptiningsih E. dan V. Vony Rorong, 2008. Pengolahan Hasil Perikanan. Penerbit PT. Citra Aji Pratama, Yogyakarta.

Trilaksani W, Bambang., 2008.Dasar Diversifikasi dan Pengembangan Produk Perikanan. [Skripsi] Departemen Teknologi Hasil Perairan Fakultas Perikanan dan Ilmu Kelautan. IPB. Bogor.

Yustianti, 2013. Formulasi Bubur Instan Sumber Protein Menggunakan Komposit Tepung Kacang Merah (Phaseolus vulgaris l.) Dan Pati Ganyong (Canna edulis kerr.) Sebagai makanan pendamping asi (MP-ASI). [Skripsi] Departemen Gizi Masyarkat Fakultas Ekologi Manusia. IPB. Bogor. 